\title{
Letter; Are Students Who do not Complete their Medical School Education Abandoned? Is More Help Needed?
}

\author{
Pedro Mancias ${ }^{1,3}$ and Roger J. Bick ${ }^{*, 2,3}$
}

\author{
${ }^{1}$ Departments of Pediatrics and Neurology; ${ }^{2}$ Pathology and Laboratory Medicine; ${ }^{3}$ UTMSH Academy of Master Educa- \\ tors, University of Texas Medical School Houston, Texas 77030
}

\begin{abstract}
During our teaching we have been confronted with a number of stressed students over the years and yet there have been relatively few discussions, workshops or group meetings no, how to help them face life after medical school if they should fail to complete their studies. We were concerned about this, especially as there are relatively easy steps that can be taken to help, and the cost of medical school increasing leading to increased debt with nothing to show for it. Tuition this year will range from $\$ 28,000$ to $\$ 50,000$ at a public and private institution respectively, with total costs from $\$ 50$ $\$ 70,000$.

Using a simple search of a number of medical school and blog sites, we formulated a simple tool that would at least, we hope, give some guidance to students that leave medical school early. It is hoped that this link table will be developed, updated and expanded further in the future so that these bright, degree-holding people do not find themselves suddenly cast adrift.
\end{abstract}

Keywords: Medical students, assistance, education, stress, guidance for medical students, opportunities, psychological and educational, support.

\section{STUDY PURPOSE}

It is inevitable that teachers will have to deal with stressed students, yet there have been relatively few discussions, workshops or group sessions in education meetings and symposia as to how to help some of these individuals face life when they fail to complete medical school, or even as to whether it is part of our job as teaching faculty. There are simple steps that can be taken to offer help and the lack of these gave us concern and directed us to determining how to funnel individuals into a process in which the burdens of accrued loans and future employment might not be insurmountable. We felt that such an effort was timely, given that tuition in 2011 averaged $\$ 29,000$ at a public institution to $\$ 47,000$ at a private school and with total costs of $\$ 50$ \$70,000 (http://www.amaassn.org/amednews/2012/08/27/prsb0827.htm).

Using a simple search of medical school sites and blogs, we compiled a simple list that would give some guidance to those students that leave medical school early, with the hope that this link table will be developed, updated and further expanded so that these intelligent, degree-holding people, do not find themselves in a situation that they are unable to cope with [1, 2].

\section{Is it Our Place to Help Students who Leave Medical School?}

"Right now you feel like a big, fat failure", (Birdie Conrad, You've Got Mail, 1998, Warner Bros.). That might be

\footnotetext{
*Address correspondence to this author at the University of Texas Medical School at Houston, MSB 2.288, 6431 Fannin Street, Houston, TX 77030, USA; Tel: 713-500-5406; Fax: 713-500-0730;

E-mail: Roger.J.Bick@uth.tmc.edu
}

the thought running through a student's head upon realizing that their time and studies at a chosen school are over and that they are unlikely to fulfill their dream of becoming a physician. What do they do next? Is there a help network that they can turn to which is both readily available and useful?

Many people involved in teaching are frequently upset when they see a student struggle, knowing that the end result is likely that of 'dropping out', and that depression might be a major problem, making the need for the initiation of intervention and considerations of solutions something that must occur quickly. While mechanisms and resources are always in place to help students advance and remain within that school, this is not enough for students that are 'forced' to leave and who face a lack of assistance [3].

What happens next? What do these students do? How do they know what choices are available and who is there to help them? Stress levels increase, depression often follows and dire outcomes can result [4]. To allay some of their fears, we suggest that help resources using a simple list of links are made available to students, hopefully providing them with a focus on their future and offering a positive distraction. They would benefit greatly if guidance was available in taking that important first step. We also suggest that a structured assistance program be required in every medical school, as well as being offered by professional, national and international organizations. The need for help is just as important as for those that do complete their studies.

Paul and colleagues [5] surveyed a large number of medical schools to determine if they had help resources available for solving academic problems. Somewhat surprisingly, only $79 \%$ of the schools provided comprehensive support services 
and these almost always focused on helping to keep students in that school, not providing help for students who had to leave. As the authors stated, "Medical schools need to take a proactive approach in helping students develop the necessary skills that can prevent academic difficulties". However, if these difficulties are not overcome, there must be continued help.

Numbers of medical students who leave and their rea$\operatorname{son}(\mathrm{s})$

To gain a better understanding as to why students left medical school, a relatively concise internet search of medical and dental school home pages was performed using a number of search engines, in order to find discussion sites, blogs, medical journals and education journals that included student-help resources. Search parameters were subsequently expanded to include students who had failed to gain entry into a US medical school, and understand where they next went for information and assistance. A willing group of students at this medical school also gave their opinions as to the need for a help program, as well as the likely decisions they would make in a situation of both non-acceptance to medical school or subsequent failure to complete their studies successfully.

With assistance from our Student Affairs office, attrition rates and reasons for leaving UTMSH were tabulated for 1995-2010 https://med.uth.edu/admissions/current-students/. Medical school leaving rates were generally reported on many internet sites as $6-8 \%$ in the first year and $2-4 \%$ in further years, the attrition rate decreasing the more years completed. It is not unheard of for third and even fourth year students to decide that medicine is not for them however (http://citystreams.com/2008/07/17dropping-out-of-medicalschool-uncensored). The annual attrition rate for this medical school, with associated reasons for leaving, is shown in Table 1.

Table 1. Reasons and Rates of Attrition Over a 15 Year Period at UTMSH

\begin{tabular}{|l|l|}
\hline Reasons for Leaving & (\%) \\
\hline \hline Poor academic performance & $(30 \%)$ \\
\hline Failure to complete all requirements & $(10 \%)$ \\
\hline Career change & $(44 \%)$ \\
\hline Health concerns & $(6 \%)$ \\
\hline Family needs & $(9 \%)$ \\
\hline Other & $(1 \%)$ \\
\hline
\end{tabular}

\section{What Do Students Actually Do When They Leave? What are The Repercussions?}

An expanded search with an increased number of responses gave us a good idea as to where students who left medical school, as well as those who failed to gain entry into a United States medical school, next went for information and assistance. A generic question, "What do students do if they drop out of medical school?", was entered into four search engines (Google, Yahoo, Bing and PubMed) and 10,000,600 'hits' were returned which, after suitable paring, yielded 68 links specific to medical school students. Opin- ions from these sites were collated into four 'general' groups regarding choices as to what students actually did or thought they would do. Links were listed and grouped based on the answers, yielding a resource that might be a reasonable starting point for enabling students to pursue potential employment and further study possibilities (Table 2). The groups are:

\section{Group 1}

Continuation of their studies at an offshore/other college;

\section{Group 2}

Exploring the possibilities of transferring into another program such as from medicine to law or dentistry for example;

\section{Group 3}

Pursuing other studies related to medicine or science such as graduate school (Masters/PhD), or entering a study program such as physician's assistant;

\section{Group 4}

Obtaining employment, but with the intention of returning to medical school if and when possible.

Column 1 of Table 2 lists properties that students stated they would want in their future choices, Column 2 of Table 2 lists potential jobs that encompassed these preferences, while column 3 lists suggestions and resources to assist in considering alternative vocations and study programs.

The most common response from students was that they would strongly consider the chance to re-enter medical school, with the next preference being to gain a doctorate in a science discipline, preferably in a field that included patient interaction, such as public health. Table $\mathbf{3}$ includes more useful resources as well as potential pitfalls.

\section{Resources Currently Available and Frequently Used}

There is ample evidence that associates major health concerns with unsuccessful students and it is very apparent that much of the help they get is gleaned from sites and blogs such as College Confidential (http://talk.collegeconfidential. com) and Live Journal (http://community.livejournal.com). Much of the content on these sites adds support to our belief that there is a lack of resources to help early medical school leavers, and we have included warnings against bad advice such as entry into an "off-shore" medical college, in which graduation often does not result in employment as a physician in the United States (http://www.admissionsconsultants. com/medical/caribbean_med_schools.asp), whereas attending Ross University might be a viable route to pursue because of clinical training in the United States being offered by this school (http://www.rossu.edu/medical-school/).

\section{OUR CONCLUSIONS}

The Carlsen and Bloise paper [3] states what has been a focus for many institutions of higher education, that many students are not prepared for college and possible failure which, for some, will unfortunately be the outcome. Early entry programs, targeted testing, and such undertakings help immensely, but there is still the inevitable problem regarding students who do not succeed [4]. 
Table 2. Help and Assessment Table of Potential Vocations and the Pluses and Negatives of Those Fields, Including Search Links

\begin{tabular}{|c|c|c|}
\hline $\begin{array}{l}\text { Responses to Job } \\
\text { WANTS AND } \\
\text { DON'T WANTS }\end{array}$ & POSSIBLE VOCATIONS & RESOURCES \\
\hline Patient contact & $\begin{array}{l}\text { Nursing, dentistry, Physicians assistant, dental } \\
\text { hygiene, social worker, epidemiology/public } \\
\text { health, clinical research }\end{array}$ & $\begin{array}{l}\text { http://www.allnursingschools.com/ } \\
\text { http://www.dentalsite.com/dentists/densch.html } \\
\text { http://www.gradschools.com/ListingFunctions/SearchResults.aspx?SubjectId } \\
\text { =315\&Country=USA\&State=\&ProgramType= } \\
\text { http://www.adha.org/careerinfo/dir_education.htm } \\
\text { http://www.dentalsite.com/hygienists/ } \\
\text { http://www.ceph.org/ } \\
\text { http://www.universities.com/Distance_Learning/Degrees_PhD_Programs_E } \\
\text { pidemiology.html } \\
\text { https://www.aamc.org/ }\end{array}$ \\
\hline People contact & $\begin{array}{l}\text { Law school, nursing school, dental school, public } \\
\text { health }\end{array}$ & $\begin{array}{l}\text { http://en.wikipedia.org/wiki/List_of_law_schools_in_the_United_State } \\
\text { http://en.wikipedia.org/wiki/List_of_nursing_schools_in_the_United_State } \\
\text { http://dentistry.about.com/od/dentalschoolsbystate/Dental_Schools_in_the_U } \\
\text { nited_State.htm } \\
\text { http://www.asph.org/document.cfm?page=200 }\end{array}$ \\
\hline $\begin{array}{l}\text { Further learning op- } \\
\text { portunities }\end{array}$ & Nursing school, graduate school, teaching & $\begin{array}{l}\text { http://en.wikipedia.org/wiki/List_of_nursing_schools_in_the_United_State } \\
\text { http://grad-schools.usnews.rankingsandreviews.com/best-graduate- } \\
\text { schools/top-health-schools } \\
\text { http://www.getdegrees.com/p/teaching-degrees }\end{array}$ \\
\hline Financial soundness & Law school, nursing school, dental school & $\begin{array}{l}\text { http://en.wikipedia.org/wiki/List_of_law_schools_in_the_United_State } \\
\text { http://en.wikipedia.org/wiki/List_of_nursing_schools_in_the_United_State } \\
\text { http://dentistry.about.com/od/dentalschoolsbystate/Dental_Schools_in_the_U } \\
\text { nited_State.htm }\end{array}$ \\
\hline $\begin{array}{l}\text { Chance for advance- } \\
\text { ment }\end{array}$ & $\begin{array}{l}\text { Law school, dental school, graduate school, } \\
\text { (nursing school), Teaching }\end{array}$ & $\begin{array}{l}\text { http://en.wikipedia.org/wiki/List_of_law_schools_in_the_United_State } \\
\text { http://en.wikipedia.org/wiki/List_of_nursing_schools_in_the_United_State } \\
\text { http://dentistry.about.com/od/dentalschoolsbystate/Dental_Schools_in_the_U } \\
\text { nited_State.htm } \\
\text { http://grad-schools.usnews.rankingsandreviews.com/best-graduate- } \\
\text { schools/top-health-schools } \\
\text { http://www.getdegrees.com/p/teaching-degrees }\end{array}$ \\
\hline $\begin{array}{l}\text { High standing in soci- } \\
\text { ety/prestige }\end{array}$ & Law School, dental school & $\begin{array}{l}\text { http://en.wikipedia.org/wiki/List_of_law_schools_in_the_United_State } \\
\text { http://dentistry.about.com/od/dentalschoolsbystate/Dental_Schools_in_the_U } \\
\text { nited_State.htm }\end{array}$ \\
\hline Job security & Law School, Dental school, Nursing School & $\begin{array}{l}\text { http://en.wikipedia.org/wiki/List_of_law_schools_in_the_United_State } \\
\text { http://dentistry.about.com/od/dentalschoolsbystate/Dental_Schools_in_the_U } \\
\text { nited_State.htm } \\
\text { http://en.wikipedia.org/wiki/List_of_nursing_schools_in_the_United_State }\end{array}$ \\
\hline $\begin{array}{l}\text { Respected higher } \\
\text { degree }\end{array}$ & Law, Dentistry, Nursing, Teaching & $\begin{array}{l}\text { http://en.wikipedia.org/wiki/List_of_law_schools_in_the_United_State } \\
\text { http://en.wikipedia.org/wiki/List_of_nursing_schools_in_the_United_State } \\
\text { http://www.getdegrees.com/p/teaching-degrees }\end{array}$ \\
\hline Help people & $\begin{array}{l}\text { Law, Dentistry, Nursing, Public Health, Osteo- } \\
\text { pathic Medicine (Massage therapist, Rehabilita- } \\
\text { tion) }\end{array}$ & $\begin{array}{l}\text { http://namtonline.com/ } \\
\text { http://www.nationalrehab.org/cwt/external/wcpages/divisions/arts.aspx }\end{array}$ \\
\hline \multicolumn{3}{|c|}{ NEGATIVES } \\
\hline Poor salary & \multicolumn{2}{|l|}{ Early law, dental hygiene, public health, teaching } \\
\hline Bad working conditions & \multicolumn{2}{|c|}{ Multiple situations, especially teaching, low-income areas, etc are big factors; maybe lack of advancement chances } \\
\hline Long hours, poor salary & \multicolumn{2}{|c|}{ Nursing, Sometimes early law, public health/protection services, teaching } \\
\hline No advancement & \multicolumn{2}{|c|}{ Teaching (Location factor), public health, social work. } \\
\hline
\end{tabular}


Table 2. Contd.....

\begin{tabular}{|c|c|c|}
\hline $\begin{array}{c}\text { Responses to Job } \\
\text { WANTS AND } \\
\text { DON'T WANTS }\end{array}$ & \multicolumn{1}{|c|}{ POSSIBLE VOCATIONS } & RESOURCES \\
\hline \hline Continuous supervision & Nursing, Teaching \\
\hline
\end{tabular}

Table 3. Listing of Possible Routes to a Terminal Medical Degree, Plus Suggested Other Sites that Might be Suitable for Consideration

\begin{tabular}{|c|c|}
\hline RESOURCE/INSTITUTION & COMMENTS \\
\hline $\begin{array}{l}\text { ROSS UNIVERSITY } \\
\text { http://www.rossu.edu/medical school }\end{array}$ & Fifth year-Miami, FL and Saginaw, MI as well as Dominica and Grand Bahama \\
\hline $\begin{array}{l}\text { UNIVERSITY OF GUADALAJARA } \\
\text { http://www.uag.edu/medicine/med4.htm } \\
\text { http://www.uag.edu/medicine/curriculum/fifth_year.php }\end{array}$ & $\begin{array}{l}\text { Close to US; Fifth year options available in NY; good match rate in USA; MUST perform } \\
\text { year of social work in Mexico if intending to practice in USA; } 2 \text { entering classes per year; } \\
\text { North American Students Association; Mexican-Spanish only in third and fourth years }\end{array}$ \\
\hline $\begin{array}{l}\text { FIFTH YEAR PROGRAMS - } \\
\text { http://www.uag.edu/medicine/curriculum/fifth_year.php }\end{array}$ & $\begin{array}{l}\text { BE CAREFUL!!! SOME PROGRAMS ARE MORE TROUBLE THAN THEY ARE } \\
\text { WORTH AND IT MIGHT NOT BE THE BEST THING TO DO. BE SURE THAT THE } \\
\text { LICENSURE REQUIREMENTS TO PRACTICE IN THE USA ARE IN PLACE. SOME } 5^{\mathrm{TH}} \\
\text { YEAR PATHWAYS WERE HALTED. }\end{array}$ \\
\hline $\begin{array}{l}\text { SAINT JAMES SCHOOL OF MEDICINE } \\
\text { http://www.sjsm.org/ }\end{array}$ & $\begin{array}{l}\text { Some accreditation links with USA and UK. The charter GUARANTEES clinical rotations at } \\
\text { US hospitals and USMLE-based instruction }\end{array}$ \\
\hline http://www.valuemd.com/stjames/ & $\begin{array}{l}\text { Lots of 'other' medical school links here. But remember, if you failed, it will be more difficult } \\
\text { to get into medical school or dental school. Some people try Eastern European schools, but } \\
\text { distance, cost, depression, etc are often major hurdles to face. }\end{array}$ \\
\hline $\begin{array}{l}\text { LAW SCHOOL } \\
\text { http://stu.findlaw.com/schools/fulllist.html }\end{array}$ & $\begin{array}{l}\text { Difficult with a failure at graduate level, but call the school you are interested in. Don't be } \\
\text { disappointed if you FAIL to get accepted and you'd have to do an LSAT. But acceptance is } \\
\text { unlikely }\end{array}$ \\
\hline $\begin{array}{l}\text { PHARMACEUTICAL SCIENCE } \\
\text { http://www.gradschools.com/ListingFunctions/SearchRes } \\
\text { ults.aspx?SubjectId=308\&Country=USA\&State=\&Progra } \\
\text { mType= }\end{array}$ & $\begin{array}{l}\text { Some colleges do offer a distinct Pharmaceutical program, distinct from pharmacy. Again, } \\
\text { chance here due to undergraduate and graduate studies. }\end{array}$ \\
\hline $\begin{array}{l}\text { TOXICOLOGY } \\
\text { http://www.universities.com/edu/Doctors_degrees_in_To } \\
\text { xicology.html }\end{array}$ & $\begin{array}{l}\text { Unlikely to be too much patient interaction if that is what you desire, but certainly people } \\
\text { contact especially through work with contamination, DEA, etc. Might be something not con- } \\
\text { sidered }\end{array}$ \\
\hline PUBLIC HEALTH http://www.asph.org/ & $\begin{array}{l}\text { Good site and you never know. Choices from here into socialized medicine, epidemiology, } \\
\text { smoking cessation, etc. Some successes here in the past with students leaving medical school. } \\
\text { Worth a look. }\end{array}$ \\
\hline
\end{tabular}


Table 3. Contd.....

\begin{tabular}{|l|l|}
\hline \multicolumn{1}{|c|}{ RESOURCE/INSTITUTION } & \multicolumn{1}{c|}{ COMMENTS } \\
\hline \hline GRAD SCHOOL http://www.gradschools.com/ & $\begin{array}{l}\text { Start with this site and then select area(s) of interest. Some schools are loath to take you if you } \\
\text { have been forced to leave medical or dental school. However, there are a few that will look at } \\
\text { what you have passed and take you in. However, grad school in biomedical sciences isn't well } \\
\text { paid and when you get your degree, masters or PhD, finding a lab to work in at decent money } \\
\text { is again difficult. Think what to do with your degree after you leave graduate school, as there } \\
\text { are choices. }\end{array}$ \\
\hline $\begin{array}{l}\text { DOCTOR OF OSTEOPATHIC MEDICINE } \\
\text { http://www.txosteo.org/ }\end{array}$ & $\begin{array}{l}\text { Not a bad option IF, and I say IF, you can get accepted. DO schools are appreciated much } \\
\text { more in the media and in the public eye and many DO graduates now practice in 'conven- } \\
\text { tional' medicine settings. DO school is difficult to get into and if it wasn't your first choice } \\
\text { and if you are doing the application simply because you failed medical/dental school, then } \\
\text { http://www.physicianscientists.org/careers/training/do- } \\
\text { phd }\end{array}$ \\
\hline GOOD, HELPFUL SITES & http://www.studentdoctor.net/2009/07/caribbean-medical-schools-a-good-option/ \\
\hline
\end{tabular}

For the unsuccessful few, medical schools are usually in medical centers and close to other health and medicine facilities, which offer many possible alternatives in the medical field. It would therefore only take a minimum of effort for colleges to assemble a list of links, including potential employers and areas of employment, so that 'leaving' students sense the possibilities and lose the anguish.

Our searches found that the major sources for information and assistance for students who prematurely leave medical school is via the internet and blogs, with only a few medical schools having the necessary resources to assist students in career changes and overcoming accrued financial burdens. This should be of major concern to schools, faculty, students, parents and education authorities and it is something that must be considered as costs increase, even though it has been a topic of discussion by departments of education, government entities and accrediting bodies.

It is not the intention of this paper to compile a complete listing of links, opportunities or alternative degree programs, but to demonstrate with the included table that this might be a good starting point and that a fuller listing will be subsequently generated and readily available.

In the preparation of this manuscript, many blogs and viewpoint pages were accessed and, as would be expected, there was an enormous amount of ire, angst, confusion, despair and depression shown by many of the writers. There were very few positives coming from the communications and views as to their time at medical school. For example, a piece that appeared on the previously noted Live Journal (http://community.livejournal.com) included the statement from a first year in medical school, "I almost literally jumped out of a third floor window". The writer also made the observation that after leaving medical school, "It's been tough trying to free myself from the medically-oriented mindset I've had my entire life". Ahmed and colleagues noted a "considerable amount of depression and anxiety among doctors and students", and concluded that much more needs to be done with this often overlooked problem [6]. When students begin to feel anxious and anxiety develops into depression, their enjoyment of medical school life, and their overall quality of life, are greatly impacted [7] and so it is advisable that medical schools ensure that emotional support is available at all times.

An interesting post was seen on the Experience Project page ([8]; http://www.experienceproject.com/stories/Dropped-Out-Of-Medical-School/96236) addressing the concerns of a student who was on leave of absence, but who was welcome to return to that medical school. This person stated that "just the thought of returning to medical school makes me almost suicidal". What could possibly drive an intelligent person this far, and why wasn't there help or intervention available before this stage was reached? This experience includes feelings that are eerily reminiscent of the sense of loss described by Elisabeth Kubler-Ross [9]. The need for help in higher education has become more recognized [10, 11 ] and this is a major positive, but the need for continuing help is sorely lacking.

This paper suggests that support for students must be available for those who are in the unenviable position of having to leave medical school, a distressing time that comes after paying significant amounts of money and accruing a substantial debt, as well as spending many sleepless hours studying for exams that lead them to unhealthy regimens and increased stress. Schools accept students, willingly take the fees, then let the less fortunate leave with no direction, no advice, and often in a daze as to what they should do next or where they should go.

As teachers and educators we have an obligation, a duty that should continue even when a student has problems that result in them leaving medical school early. A paper by Jadoon and colleagues concluded, “.....medical students constitute a vulnerable group that has a high prevalence of psychiatric morbidity comprising of anxiety and depression" [12]. This vulnerability does not magically disappear unfortunately when given a change in circumstances.

\section{CONFLICT OF INTEREST}

The authors confirm that this article content has no conflicts of interest.

\section{ACKNOWLEDGEMENTS}

The authors express their gratitude to Ms. Patricia Caver, Director of Student Affairs and Admissions, Dr. Margaret 
McNeese and Dr. Sheela Lahoti, Associate and Assistant Deans of Students affairs respectively for there help in compiling the student attrition rates and reasons; to the Office of Student Affairs for their support of this project; and to Eleni Gianacakes and Stephanie Logterman, for their help and enthusiasm in collecting responses.

We also appreciate the insights and discussions with Dr. Diane Hickson-Bick, Director of the graduate student molecular pathology program and chair of the medical school graduate education committee.

\section{REFERENCES}

[1] Drybe LN, Shanafelt TD. Commentary: medical student distress: a call to action. Acad Med 2011; 86: 801-3.

[2] Drybe LN, Harper W, Durning SJ, et al. Patterns of distress in US medical students. Med Teach 2011; 33: 834-9.

[3] Carlsen BA, Bloise M. Why students leave college. (Available at: http://ezinear-ticles.com; [Accessed $10^{\text {th }}$ Oct 2009].
[4] Dyrbye LN, Thomas MR, Massie S, et al. Burnout and suicidal ideation among US medical students. Ann Int Med 2008; 149: 334-41.

[5] Paul G, Hinman G, Dottl S, Passon J. Academic development: a survey of academic difficulties experienced by medical students and support services provided. Teach Learn Med 2009; 21: 254-60.

[6] Ahmed I, Banu H, Al-Fageer R, Al-Suwaidi R. Cognitive emotions: depression and anxiety in medical students and staff. J Crit Care 2009; 24: e1-7.

[7] Paro HB, Morales NM, Silva CH, et al. Health-related quality of life of medical students. Med Educ 2010; 44: 227-35.

[8] Experience Project: Personal stories, support and advice from 40 members. (Available at: http://www.experienceproject.com/groups/ DroppedOut- Of-Medical-School/49241) [accessed $10^{\text {th }}$ Jan, 2013].

[9] Kübler-Ross E. On Death and Dying. NY: Macmillan 1969.

[10] O'Rourke M, Hammond S, O'Flynn S, Boylan G. The medical student stress profile: a tool for stress audit in medical training. Med Educ 2010; 44: 1027-37.

[11] Nyer M, Hold DJ, Pedrelli P, et al. Factors that distinguish college students with depressive symptoms with and without suicidal thoughts. Ann Clin Psychiatry 2013; 25: 41-9.

[12] Jadoon NA, Yaqoob R, Raza A, Shehzad MA, Choudhry ZS. Anxiety and depression among medical students: a cross-sectional study. J Pak Med Assoc 2012; 60: 699-702.

(C) Mancias and Bick; Licensee Bentham Open.

This is an open access article licensed under the terms of the Creative Commons Attribution Non-Commercial License (http://creativecommons.org/licenses/by-nc/3.0/) which permits unrestricted, non-commercial use, distribution and reproduction in any medium, provided the work is properly cited. 